\title{
CRYSTAL STRUCTURE, SPECTROSCOPIC AND MAGNETIC PROPERTIES OF A NEW IRON(III) COMPLEX
}

\author{
J. Abdelhak, S.N. Cherni, M.F. Zid, A. Driss \\ Laboratoire de Matériaux et Cristallochimie, Département de Chimie, Faculté des Sciences de Tunis, Université \\ de Tunis, Tunis, Tunisie \\ E-mail: jawher.abdelhak@ipein.rnu.tr
}

Received November, 26, 2013

Revised-March, 9, 2014

\begin{abstract}
We report herein the synthesis and physicochemical characterization of a new mixed-ligand iron(III) complex of the formula $\left(\mathrm{C}_{5} \mathrm{H}_{6} \mathrm{ClN}_{2}\right)\left[\mathrm{Fe}\left(\mathrm{C}_{2} \mathrm{O}_{4}\right)_{2}\left(\mathrm{H}_{2} \mathrm{O}\right)_{2}\right] \cdot 2 \mathrm{H}_{2} \mathrm{O}$. This compound is prepared by slow evaporation at room temperature and characterized by single crystal X-ray diffraction. It is characterized by IR and UV-VIS spectra and thermal analysis (TG and DTA). In this compound, the iron ion has a slightly distorted square bipyramidal environment, coordinated by two chelating oxalate ions and two water molecules. Structural cohesion is essentially established by $\pi-\pi$ interactions between the rings of pyridine groups and intermolecular hydrogen bonds connecting the ionic entities and uncoordinated water molecules. Magnetic susceptibility measurements exhibit the paramagnetic behavior at high temperatures. However, at low temperatures, the magnetic data show the occurrence of weak antiferromagnetic intermolecular interactions between the local spins.
\end{abstract}

DOI: $10.15372 / \mathrm{JSC} 20150407$

Ke y w o r d s: crystal structure, iron(III) complex, thermal behavior, visible and ultraviolet spectrometers, magnetic properties.

\section{INTRODUCTION}

Several years ago, numerous oxalate complexes have been synthesized and investigated due to their extensive application in various fields such as medical, pharmaceutical, biological, and even industrial $[1,2]$. This is due to the ability of the oxalate ligand to efficiently transmit magnetic interactions through its bridging mode [ 3 ]. Its planar shape, negative charge, and good donor ability because of the presence of four oxygen donors make this ligand very appropriate to build coordination polymers in its interaction with metal ions. The versatility of oxalate as a ligand is well illustrated by the variety of coordination modes.

Further, because of our interest in the magnetic properties of polymeric three-dimensionally linked complexes with chelating oxalate ions as bridging ligands, further studies have been extended to the synthesis of transition metal compounds containing oxalate and its derivates [ $4-8$ ].

A powerful synthetic strategy to design such materials is supramolecular chemistry based on selfassembly processes of two different components [9]. In fact, this second ligand can contribute to the structure cohesion acting as a hydrogen bond donor through the two nitrogen atoms. Additional stability can also be offered by the $\pi-\pi$ stacking interaction of pyridine rings $[10,12]$. In this context, we quote the protonated 2-amino-5-chloropyridinium as a cationic counter-ion.

(C) Abdelhak J., Cherni S.N., Zid M.F., Driss A., 2015 
Fig. 1. Powder XRD pattern $\left(\mathrm{Cu} K_{\alpha}\right)$ of $\left(\mathrm{C}_{5} \mathrm{H}_{6} \mathrm{ClN}_{2}\right)$. $\cdot\left[\mathrm{Fe}\left(\mathrm{C}_{2} \mathrm{O}_{4}\right)_{2}\left(\mathrm{H}_{2} \mathrm{O}\right)_{2}\right] \cdot 2 \mathrm{H}_{2} \mathrm{O}:(a)$ experimental, $(b)$ simulated

This paper is a continuation of the study of the $\mathrm{M}^{n+}$ - oxalate-second ligand system, where we report its synthesis and structural characterization as well as the spectroscopic, thermal, and magnetic properties of a new compound $\left(\mathrm{C}_{5} \mathrm{H}_{6} \mathrm{ClN}_{2}\right)\left[\mathrm{Fe}\left(\mathrm{C}_{2} \mathrm{O}_{4}\right)_{2}\left(\mathrm{H}_{2} \mathrm{O}\right)_{2}\right] \cdot 2 \mathrm{H}_{2} \mathrm{O}$.

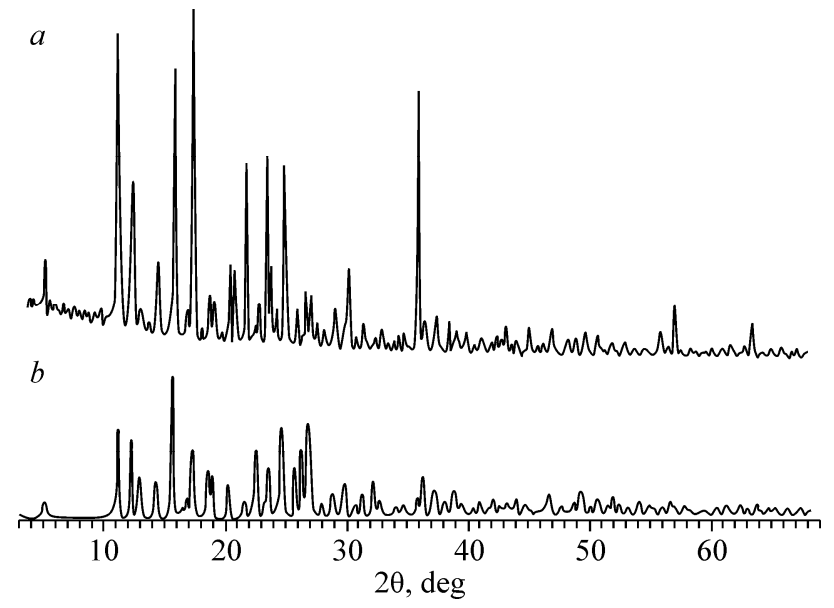

EXPERIMENTAL

Materials and physical measurements. All chemicals were commercially available and used without further purification. A TG/DTA 92 SETARAM thermal analyzer was employed for the investigation of the thermal behavior in the Ar atmosphere from room temperature to $600{ }^{\circ} \mathrm{C}$ and a UV-Vis spectrum was measured on a Perkin Elmer Lambda $20 \mathrm{UV} / \mathrm{V}$ is spectrometer in the range 200$700 \mathrm{~nm}$.

Magnetic susceptibility measurements of a polycrystalline sample were carried out using a quantum design (superconducting quantum interference device SQUID) magnetometer in the temperature range $2-300 \mathrm{~K}$ at a magnetic field of $0.1 \mathrm{~T}$. The susceptibility data were corrected for the diamagnetism estimated from Pascal's tables [13].

Synthesis. This compound was prepared by the reaction of iron nitrate $\mathrm{Fe}\left(\mathrm{NO}_{3}\right)_{3} \cdot 9 \mathrm{H}_{2} \mathrm{O}$, 2-amino5-chloropyridine, and oxalic acid dihydrate respectively (1:1:2) in ethanol. The resulting mixture was heated to the boiling point and stirred for three hours. A red precipitate formed immediately. After two weeks single red crystals were obtained by slow evaporation from an aqueous solution at room temperature. Anal. Found: C 17.12, H 2.53, Fe 11.05, N 4.17, O 35.46, Cl 6.14. Calc. for $\mathrm{C}_{9} \mathrm{H}_{14} \mathrm{FeN}_{2} \mathrm{O}_{12} \mathrm{Cl}$ (M.W. 433.52): C 17.3, H 2.2, Fe 11.2, N 4.5, O 35.3, Cl 6.2.

Crystal structure determinations and refinements. The powder XRD pattern was recorded on crushed single crystals in the $2 \theta$ range $5-70^{\circ}$ using $\mathrm{Cu} K_{\alpha}$ radiation $(\lambda=1.5406 \AA$ ) using a brand PANanalytical X'Pert PRO diffractometer. The XRD pattern was entirely consistent with the structure determined using single crystal XRD. The observed and simulated XRD patterns are shown in Fig. 1.

A prismatic red crystal $(0.3 \times 0.27 \times 0.18 \mathrm{~mm})$ was selected for the structural analysis. Diffraction data were collected at 293(2) $\mathrm{K}$ on an automatic four-circle Enraf-Nonius CAD4 diffractometer equipped with a graphite monochromator using $\operatorname{Mo} K_{\alpha}(\lambda=0.71073 \AA)$ radiation with the $w-2 \theta$ technique. Unit cell parameters and orientation matrix of the title compound were determined by the least squares treatment of the setting angles of 25 reflections in the range $10<\theta<15^{\circ}$.

The structure was solved by the standard Patterson methods and refined by the full-matrix leastsquares method on $F^{2}$ for 287 refined parameters. The computations were performed using SHELXS 97 [14] and SHELXL 97 [ 15 ]. All non-hydrogen atoms were treated anisotropically. Except the hydrogen atoms which were calculated, the others were located from a difference synthesis. The molecular plots were drawn using the Diamond program 3.0 [16].

\section{RESULTS AND DISCUSSION}

Crystal structure description. This compound crystallized in the triclinic space group $P-1$. Pertinent details for the structure determination and refinement are listed in Table 1. The perspective view of the molecular structure is depicted in Fig. 2 with atom labeling scheme; selected bond lengths and bond angles are given in Table 2. The title compounds contain the complex $\left[\mathrm{Fe}\left(\mathrm{C}_{2} \mathrm{O}_{4}\right)_{2}\left(\mathrm{H}_{2} \mathrm{O}\right)_{2}\right]^{-}$anion, 
Crystal data and structure refinement for $\left(\mathrm{C}_{5} \mathrm{H}_{6} \mathrm{ClN}_{2}\right)\left[\mathrm{Fe}\left(\mathrm{C}_{2} \mathrm{O}_{4}\right)_{2}\left(\mathrm{H}_{2} \mathrm{O}\right)_{2}\right] \cdot 2 \mathrm{H}_{2} \mathrm{O}$

\begin{tabular}{|c|c|}
\hline Formula & $\mathrm{C}_{9} \mathrm{H}_{14} \mathrm{FeN}_{2} \mathrm{O}_{12} \mathrm{Cl}$ \\
\hline Formula weight & 433.52 \\
\hline Crystal system & Triclinic \\
\hline Space group & $P-1$ \\
\hline$a, b, c, \AA$ & $7.269(1), 7.633(1), 14.887(2)$ \\
\hline$\alpha, \beta, \gamma$, deg. & $99.86(1), 92.99(1), 92.34(1)$ \\
\hline Volume, $\AA^{3}$ & $814.8(2)$ \\
\hline$Z$ & 2 \\
\hline$\rho, \mathrm{g} / \mathrm{cm}^{-3}$ & 1.767 \\
\hline$\mu, \mathrm{mm}^{-1}$ & 1.156 \\
\hline$\theta$ range, deg. & $2.70-26.97$ \\
\hline Index ranges, deg. & $-9 \leq h \leq 0,-9 \leq k \leq 9,-18 \leq l \leq 18$ \\
\hline Total data collected & 3822 \\
\hline Independent reflections & 3541 \\
\hline Reflections with $I>2 \sigma(I)$ & 3066 \\
\hline$R_{\text {int }}$ & 0.0242 \\
\hline Goodness-of-fit on $F^{2}$ & 1.077 \\
\hline$R^{\mathrm{a}} / R w^{\mathrm{b}}[I>2 \sigma(I)]$ & $0.0428 / 0.1248$ \\
\hline Largest difference peak and hole, e $/ \AA^{-3}$ & 0.615 and -0.776 \\
\hline
\end{tabular}

Selected bond lengths $(\AA)$ and angles (deg.) for $\left(\mathrm{C}_{5} \mathrm{H}_{6} \mathrm{ClN}_{2}\right)\left[\mathrm{Fe}\left(\mathrm{C}_{2} \mathrm{O}_{4}\right)_{2}\left(\mathrm{H}_{2} \mathrm{O}\right)_{2}\right] \cdot 2 \mathrm{H}_{2} \mathrm{O}$

\begin{tabular}{l|l|l|r||r|r||r|r}
\hline $\mathrm{Fe}-\mathrm{O} 1$ & $1.971(2)$ & $\mathrm{O} 1-\mathrm{Fe}-\mathrm{O} 2$ & $173.9(1)$ & $\mathrm{O} 4-\mathrm{Fe}-\mathrm{O} 6$ & $92.8(1)$ & $\mathrm{O} 2-\mathrm{Fe}-\mathrm{O} 5$ & $93.4(1)$ \\
$\mathrm{Fe}-\mathrm{O} 2$ & $1.968(2)$ & $\mathrm{O} 1-\mathrm{Fe}-\mathrm{O} 4$ & $82.7(1)$ & $\mathrm{O} 2-\mathrm{Fe}-\mathrm{O} 3$ & $83.1(1)$ & $\mathrm{O} 1-\mathrm{Fe}-\mathrm{O} 5$ & $91.4(1)$ \\
$\mathrm{Fe}-\mathrm{O} 3$ & $1.979(2)$ & $\mathrm{O} 2-\mathrm{Fe}-\mathrm{O} 4$ & $92.5(1)$ & $\mathrm{O} 1-\mathrm{Fe}-\mathrm{O} 3$ & $93.1(1)$ & $\mathrm{O} 4-\mathrm{Fe}-\mathrm{O} 5$ & $174.1(1)$ \\
$\mathrm{Fe}-\mathrm{O} 4$ & $1.972(2)$ & $\mathrm{O} 2-\mathrm{Fe}-\mathrm{O} 6$ & $91,5(1)$ & $\mathrm{O} 4-\mathrm{Fe}-\mathrm{O} 3$ & $90.6(1)$ & $\mathrm{O} 6-\mathrm{Fe}-\mathrm{O} 5$ & $87.3(1)$ \\
$\mathrm{Fe}-\mathrm{O} 5$ & $1.994(2)$ & $\mathrm{O} 1-\mathrm{Fe}-\mathrm{O} 6$ & $92.6(1)$ & $\mathrm{O} 6-\mathrm{Fe}-\mathrm{O} 3$ & $173.7(1)$ & $\mathrm{O} 3-\mathrm{Fe}-\mathrm{O} 5$ & $89.8(1)$ \\
$\mathrm{Fe}-\mathrm{O} 6$ & $1.975(2)$ & \multicolumn{1}{|l}{} & &
\end{tabular}

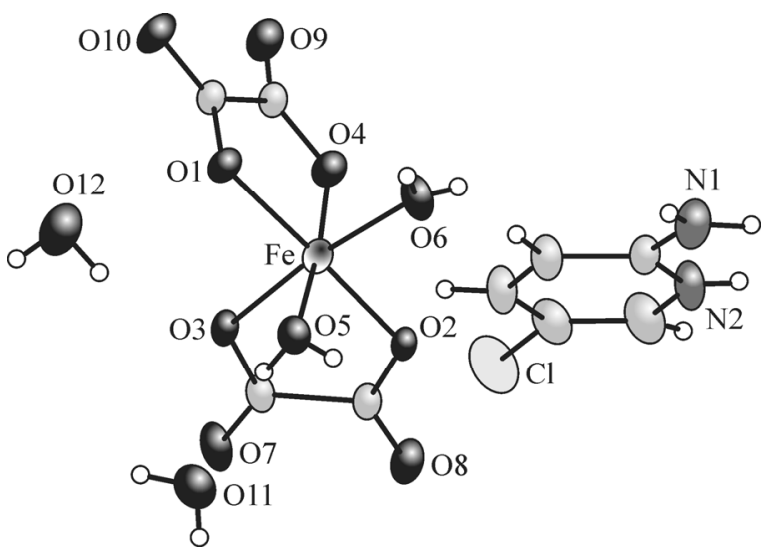

Fig. 2. Molecular structure of $\left(\mathrm{C}_{5} \mathrm{H}_{6} \mathrm{ClN}_{2}\right)\left[\mathrm{Fe}\left(\mathrm{C}_{2} \mathrm{O}_{4}\right)_{2}\left(\mathrm{H}_{2} \mathrm{O}\right)_{2}\right] \cdot 2 \mathrm{H}_{2} \mathrm{O}$ (at a $30 \%$ probability level). The $\mathrm{O} 3$ and O6 atoms occupy the axial positions; other oxygen atoms form the equatorial plane 
$\left(\mathrm{C}_{5} \mathrm{H}_{6} \mathrm{ClN}_{2}\right)^{+}$cations, and uncoordinated water molecules. The charge balance of the anion is provided by an uncoordinated 2-amino-5-chloropyridinium cation. The central atom of all anions is hexacoordinated by two oxygen atoms from cis water molecules and four carboxylate oxygen atoms from two bidentate oxalato ligands.

The $\mathrm{O} 6$ water oxygen atom and the $\mathrm{O} 3$ oxalato oxygen atom occupy the axial positions, while $\mathrm{O} 1, \mathrm{O} 2, \mathrm{O} 4$, and $\mathrm{O} 5$ form the equatorial plane. The three diagonal angles of the metal polyhedron $\left(173.7-174.1^{\circ}\right)$ deviate from the linearity, therefore the coordination geometry around the $\mathrm{Fe}(\mathrm{III})$ atom is a distorted octahedron.

The best equatorial plane is defined by the $\mathrm{O} 1, \mathrm{O} 2, \mathrm{O} 4$, and $\mathrm{O} 5$ atoms (the largest deviation from the mean plane is $0.07 \AA$ for O1) and the central atoms are by $0.03 \AA$ out of this plane, which shows a slight distortion. The $\mathrm{O}-\mathrm{Fe}-\mathrm{O}\left(82.7(1)-93.4(1)^{\circ}\right)$ bite angles are far from the ideal one of $90^{\circ}$ because of the usual small bite size of five-membered planar chelate rings formed by the bidentate oxalate ligand $[17,18]$.

Otherwise, we can say, since the resulting coordination sphere is not a perfect tetragonal pyramid, it is appropriate to use the angular structural parameter $\tau$, as suggested in [19]. The $\tau$ parameter is defined as the ratio of the two basal angle difference and $60^{\circ}$ : for the pure tetragonal pyramid $\tau=0$ and for a trigonal bipyramid $\tau=1$. In the case of both compounds, $\tau=0.07$, indicating a distorted tetragonal pyramid geometry for the metal coordination sphere.

The Fe-oxygen bond distances range from 1.968(2) $\AA$ to 1.994(2) $\AA$. These bonds are comparable with those reported for $\left[\mathrm{Fe}\left(\mathrm{H}_{2} \mathrm{O}\right)_{2}(\mathrm{ox})_{2}\right][20,21]$, where $\mathrm{Fe}-\mathrm{O}$ bond distances range from 1.901(3) $\AA$ to 2.039(2) $\AA$. However, all the $\mathrm{Fe}-\mathrm{O}$ bond contacts are in the normal range comparing to those in the similar compounds. The $\mathrm{M}-\mathrm{O}$ bond length is comparable to those reported later, reflecting the anionic character of the ligand atom. These bond distances were observed in other iron oxalato complexes.

In the oxalato ligand, the $\mathrm{C}-\mathrm{O}$ bonds with the chelating $\mathrm{O}$ atoms are unexpectedly elongated to 1.283(5) $\AA$ and 1.292(5) $\AA$; they are substantially larger than 1.219(7) $\AA$ and 1.237(4) $\AA$ of the noncoordinating one. The $\mathrm{C}-\mathrm{C}$ bond distance in the oxalate ligands is as expected for a single $\mathrm{C}-\mathrm{C}$ bond (between 1.552(9) $\AA$ and 1.554(3) $\AA$ ). The bond length values of the peripheral and inner $\mathrm{C}-\mathrm{O}$ bonds correspond well with those reported for other oxalate complexes, the shorter values being due to the greater double bond character of the free $\mathrm{C}-\mathrm{O}$ bonds [22].

The pyridine ligand is planar and the average $\mathrm{C}-\mathrm{C}(1.356 \AA)$ and $\mathrm{C}-\mathrm{N}(1.386 \AA)$ bond lengths, $\mathrm{C}-\mathrm{Cl}$ distance of the order $1.742 \AA$, the average angles $\left(120^{\circ}\right)$ within the rings are in good agreement with those currently given in the literature for pyridine non-coordinated metal complexes [23 ].

The structure can be described as segregated positive $\left(\mathrm{C}_{5} \mathrm{H}_{6} \mathrm{ClN}_{2}\right)^{+}$and negative $\left\{\left[\mathrm{Fe}\left(\mathrm{C}_{2} \mathrm{O}_{4}\right)_{2}\left(\mathrm{H}_{2} \mathrm{O}\right)_{2}\right]^{-}+2 \mathrm{H}_{2} \mathrm{O}\right\}$ layers parallel to $(001)$ and interconnected via $\mathrm{N}-\mathrm{H}$... $\mathrm{O}$ and $\mathrm{O}-\mathrm{H}$... hydrogen bonds.

In this compound, the $\left[\mathrm{Fe}\left(\mathrm{C}_{2} \mathrm{O}_{4}\right)_{2}\left(\mathrm{H}_{2} \mathrm{O}\right)_{2}\right]^{-},\left(\mathrm{C}_{5} \mathrm{H}_{6} \mathrm{ClN}_{2}\right)^{+}$cations and uncoordinated water molecules are joined through $\mathrm{O}-\mathrm{H} \ldots \mathrm{O}$ or $\mathrm{N}-\mathrm{H}$... O hydrogen bonds (the length $d(\mathrm{D} \ldots \mathrm{A})$ and the angle $\angle\left(\mathrm{D}-\mathrm{H}\right.$...A) are from 2.648(9) $\AA$ up to $2.945(9) \AA$ and from $161.1(1)^{\circ}$ up to $179.6(1)^{\circ}$ respectively) into 3D supramolecular networks (Fig. 3, Table 3). In fact, the uncoordinated water molecules (O11) play a role of both acceptors and donors while the coordinated water molecules (O5 and O6) act only as donors. As for the oxalate groups, the peripheral $\mathrm{O} 9$ and $\mathrm{O} 10$ carboxylate oxygen atoms are only acceptors. The second kind of the hydrogen bond involves the $\mathrm{N} 2$ atom which acts as a bi-connective node to link two different complex molecules.

In the crystal structure, the chloropyridinium cation units are stacked by means of face-to-face interactions among the ring system of the pyridine groups to form layers parallel to the $b c$ plane of the unit cell (Fig. 4). The interplanar short distances are of about $3.433 \AA$ and $3.896 \AA$. Obviously, the hydrogen bonds and $\pi-\pi$ interactions are responsible for the structural stability of the material.

IR spectra. The infrared spectra of the compound exhibit characteristic bands for the oxalate ligand. The characteristic bands of the oxalate bridging ligand appear at $1684 \mathrm{~cm}^{-1}, 1351 \mathrm{~cm}^{-1}$, and $764 \mathrm{~cm}^{-1}$, corresponding to $v_{\mathrm{as}}(\mathrm{CO}), v_{\mathrm{s}}(\mathrm{CO})$, and $\delta(\mathrm{O}-\mathrm{C}-\mathrm{O})$ respectively [24]. The region of the 


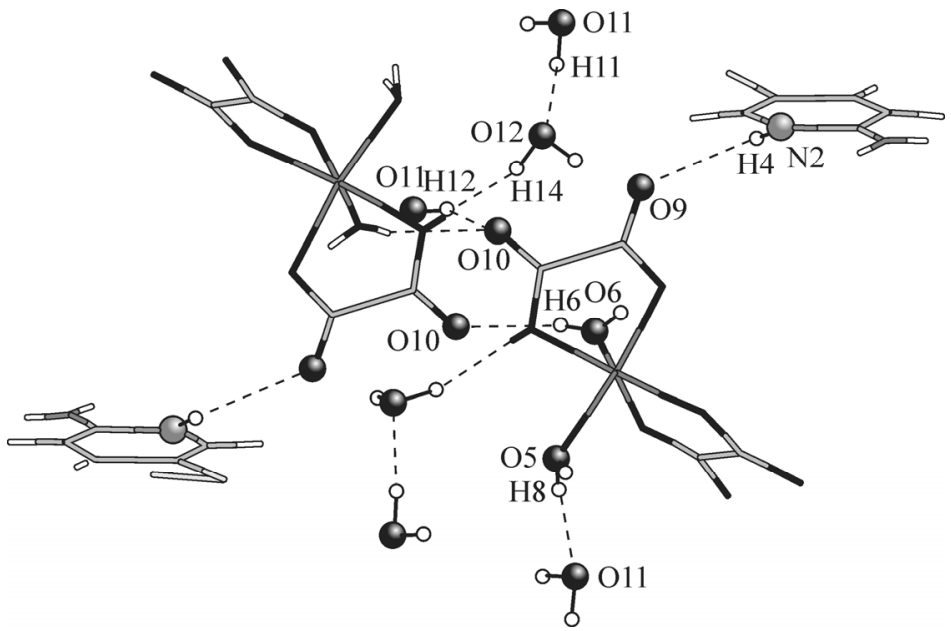

Fig. 3. Fragments of the molecular structure of $\left(\mathrm{C}_{5} \mathrm{H}_{6} \mathrm{ClN}_{2}\right)\left[\mathrm{Fe}\left(\mathrm{C}_{2} \mathrm{O}_{4}\right)_{2}\left(\mathrm{H}_{2} \mathrm{O}\right)_{2}\right] \cdot 2 \mathrm{H}_{2} \mathrm{O}$ showing well-directional hydrogen bonding interactions

Ta b l e 3

Selected hydrogen bond parameters for $\left(\mathrm{C}_{5} \mathrm{H}_{6} \mathrm{ClN}_{2}\right)\left[\mathrm{Fe}\left(\mathrm{C}_{2} \mathrm{O}_{4}\right)_{2}\left(\mathrm{H}_{2} \mathrm{O}\right)_{2}\right] \cdot 2 \mathrm{H}_{2} \mathrm{O}$

\begin{tabular}{c|l|l|c|c|c|c}
\hline \multicolumn{1}{c|}{$\mathrm{D}$} & $\mathrm{H}$ & $\mathrm{A}$ & $\mathrm{D}-\mathrm{H}$ & $\mathrm{H} \ldots \mathrm{A}$ & $\mathrm{D} \ldots \mathrm{A}$ & $\mathrm{D}-\mathrm{H} \ldots \mathrm{A}$ \\
\hline $\mathrm{O} 5$ & $\mathrm{H} 8$ & O9 & $0.70(1)$ & $1.949(6)$ & $2.648(9)$ & $179.6(1)$ \\
$\mathrm{O} 6$ & $\mathrm{H} 6$ & O11 & $0.79(1)$ & $1.995(6)$ & $2.679(9)$ & $169.2(1)$ \\
O11 & $\mathrm{H} 12$ & O10 $^{\mathrm{ii}}$ & $0.83(2)$ & $2.161(1)$ & $2.955(4)$ & $159.1(1)$ \\
O11 & H11 & O12 & $0.85(2)$ & $1.857(3)$ & $2.658(2)$ & $161.1(1)$ \\
N2 & H4 & O9 & $0.73(5)$ & $2.269(5)$ & $2.945(9)$ & $146.8(3)$
\end{tabular}

$\mathrm{D}$ - donor; A - acceptor.

Codes of symmetry: ${ }^{\mathrm{i}} 1-x, 1-y, 1-z ;{ }^{\mathrm{ii}} 1-x, 1-y,-z$.

$v_{\text {as }}(\mathrm{CO})$ and $v_{\mathrm{s}}(\mathrm{CO})$ stretching vibrations of the oxalate group often shows slight differences owing to the diverse coordination modes. The split bands are generally characteristic of the bidentate oxalate groups as terminal ligands [3]. The strong and broad absorption band at $3500-3100 \mathrm{~cm}^{-1}$ is attri-

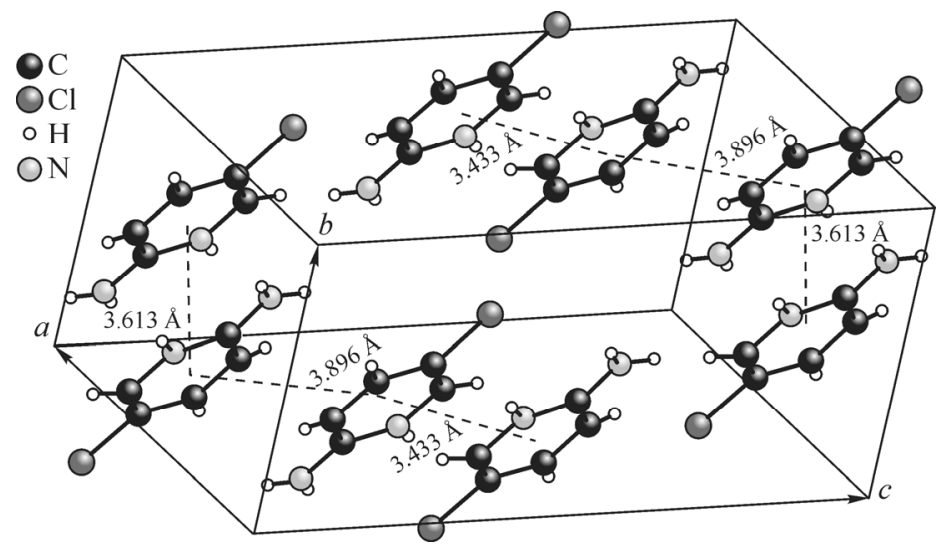

Fig. 4. View of a part of the sheet of $\left[\left(\mathrm{C}_{5} \mathrm{H}_{6} \mathrm{ClN}_{2}\right)\right]^{+}$cation entities linked by $\pi-\pi$ stacking interactions (dashed lines) between the neighboring pyridine ligands 
Fig. 5. U.v./vis spectra of

$\left(\mathrm{C}_{5} \mathrm{H}_{6} \mathrm{ClN}_{2}\right)\left[\mathrm{Fe}\left(\mathrm{C}_{2} \mathrm{O}_{4}\right)_{2}\left(\mathrm{H}_{2} \mathrm{O}\right)_{2}\right] \cdot 2 \mathrm{H}_{2} \mathrm{O}$ in ethanol

buted to the $v(\mathrm{OH})$ vibrations of water molecules in the crystal lattice as well as $v(\mathrm{C}-\mathrm{H})$ and $v(\mathrm{~N}-\mathrm{H})$ [25]. The peak located at $493 \mathrm{~cm}^{-1}$ is assigned to $v(\mathrm{Fe}-\mathrm{O})$ [26].

Additionally, the bands located in the 1650 $1400 \mathrm{~cm}^{-1}$ region are assignable to $\mathrm{C}-\mathrm{C}$ and $\mathrm{C}-\mathrm{N}$ stretching vibrations of pyridine groups [27]. Finally, the bands in the $1250-600 \mathrm{~cm}^{-1}$ region can be assigned to the $\mathrm{C}-\mathrm{Cl}$ and ring deformation absorptions

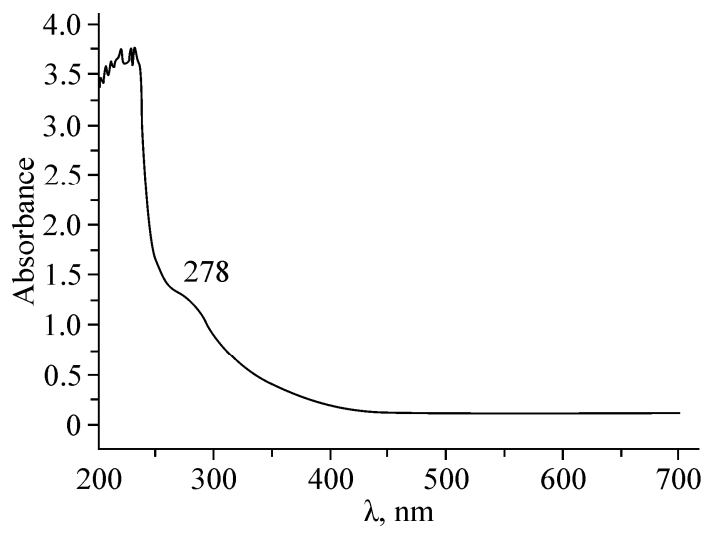
of the chloropyridinium cation.

Thermal analysis. Thermal stability of the compound has been studied by the differential thermal analysis (DTA) and thermogravimetry (TG) from room temperature to $600{ }^{\circ} \mathrm{C}$. Within this interval, several degradation steps were observed. In the interval between $80^{\circ} \mathrm{C}$ and $155^{\circ} \mathrm{C}$, the DTA trace shows an endothermic peak. The weight loss (calculated $16.61 \%$; found $16.20 \%$ ) suggests that the compound loses four water molecules in two consecutive steps; the first loss corresponds to the weakly coordinated water molecules and the second loss to the coordinated ones.

The next large step ( $\mathrm{ca} .68 \%$ ) in the decomposition curve in the temperature range of 220 $450{ }^{\circ} \mathrm{C}$ comprises the removal of pyridine cations and oxalate groups as a strongly exothermic process [28].

This technique was used to check the number of water molecules as well as the nature of connections with the network of these molecules. These results are in perfect agreement with the structural study.

Electronic spectra. Electronic spectroscopic data are obtained from the ethanol solution. Fig. 5 shows the electronic spectrum of the compound. The absorption spectra of the complex show very intense bands in UV. The spectrum is dominated by one band in UV at $278 \mathrm{~nm}$. This band can be attributed to the oxalato-to-Fe ${ }^{\mathrm{III}}$ charge transfer [29]. In the bibliography, many intense bands (not shown) are found between $210 \mathrm{~nm}$ and $250 \mathrm{~nm}$, which can be assigned to pyridine $n-\pi^{*}$ and $\pi-\pi^{*}$ transitions [30].

Magnetic measurements. Fig. 6 shows the temperature dependence of molar susceptibilities and inverse molar susceptibilities of the title complex. This compound exhibits the paramagnetic behavior, obeying the Curie-Weiss equation $\chi=\mathrm{C} /(T-\theta)$, where $C$ and $\theta$ are the Curie-Weiss constant and

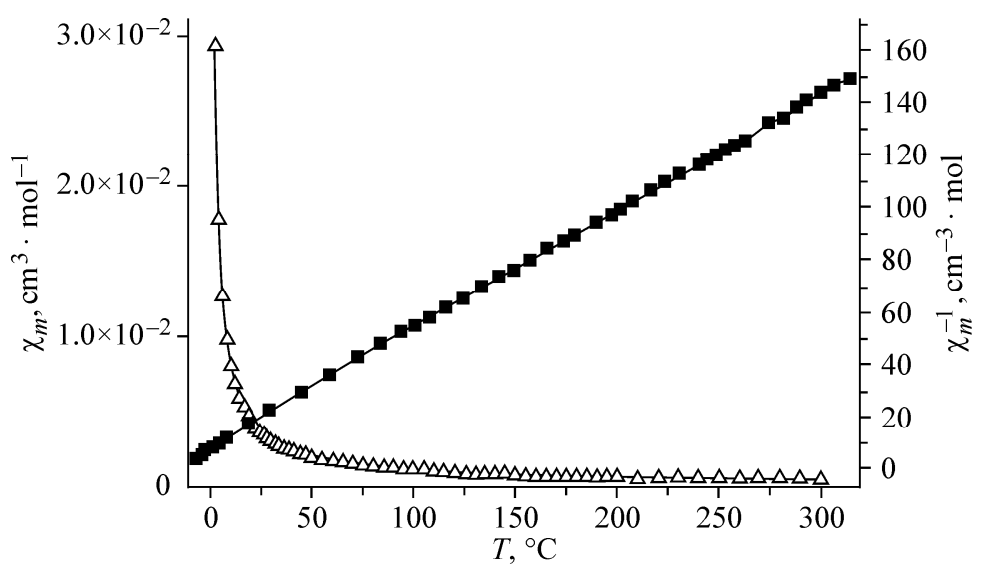

Fig. 6. Thermal dependence of $\chi_{\mathrm{m}}(\triangle)$ and $\chi_{\mathrm{m}}^{-1}(\boldsymbol{\square})$ for $\left(\mathrm{C}_{5} \mathrm{H}_{6} \mathrm{ClN}_{2}\right)\left[\mathrm{Fe}\left(\mathrm{C}_{2} \mathrm{O}_{4}\right)_{2}\left(\mathrm{H}_{2} \mathrm{O}\right)_{2}\right] \cdot 2 \mathrm{H}_{2} \mathrm{O}$ 
the magnetic coupling parameter respectively. Fitting with the Curie-Weiss equation $\chi=\mathrm{C} /(T-\theta)$ using the original program yields the values of $C$ and $\theta: 4.31 \mathrm{~cm}^{3} \cdot \mathrm{K} \cdot \mathrm{mol}^{-1}$ and $-6.23 \mathrm{~K}$ respectively. The negative $\theta$ value indicates the antiferromagnetic interactions. The effective magnetic moments at room temperature are of normal values, i.e. $5.43 \mu_{\mathrm{B}}$, which is slightly smaller than the spin-only value of $5.92 \mu_{\mathrm{B}}$.

The weak antiferromagnetic coupling observed in our compound is in agreement with the mononuclear nature of the paramagnetic iron(III) units and the large intermolecular $\mathrm{M}-\mathrm{M}$ separation across the possible exchange pathway within the supramolecular chains (the shortest $\mathrm{Fe}-\mathrm{Fe}$ separation being 5.161(1) $\AA$ ). The local anisotropy of the metal ions (zero-field splitting effects) and/or intermolecular antiferromagnetic iron-iron interactions would account for the observed decrease in $\chi_{\mathrm{m}} \cdot T$ in the range of very low temperatures, causing a deviation from the Curie law [31 ].

\section{CONCLUSIONS}

In conclusion, this paper is a study of a new mixed-ligand compound containing oxalate bridging ligands. The single crystal X-ray data show the elongated tetragonal bipyramidal coordination around the iron(III) atoms of $\left[\mathrm{Fe}\left(\mathrm{C}_{2} \mathrm{O}_{4}\right)_{2}\left(\mathrm{H}_{2} \mathrm{O}\right)_{2}\right]^{-}$anions. In addition to $\pi-\pi$ interactions between the rings of pyridine groups, the cations and uncoordinated water molecules are connected through hydrogen bonds into 3D supramolecular frameworks.

The magnetic properties indicate antiferromagnetic exchanges in this compound. Thermal analysis made it possible to confirm the number of water molecules as well as the nature of connections to the network of these molecules. These results are in perfect agreement with the structural study. Further work with mixed bridging ligands to build up novel polymers with interesting properties is in progress.

Crystallographic data and full lists of bond lengths and angles have been deposited with the Cambridge Crystallographic Data Centre, CCDC No. 968830. Copies of this information may be obtained free of charge from The Director, CCDC, 12 Union Road, CAMBRIDGE CB2 1EZ, UK (fax: +441223-336-033; e-mail: deposit@ccdc.cam.ac.uk or http://www.ccdc.cam.ac.uk).

\section{REFERENCES}

1. Haikarainen A., Sipilä J., Pietikäinen P., Pajunen A., Mutikainen I. // J. Chem. Soc., Dalton Trans. - 2001. - P. 991.

2. Ferbinteanu M., Miyasaka H., Wernsdorfer W., Nakata K., Sugiura K.I., Yamashita M., Coulon C., Clérac R. // J. Am. Chem. Soc. - 2005. - 127. - P. 3090.

3. Jia H.P., Li W., Ju Z.F., Zhang J. // J. Mol. Struct. - 2007. - 833. - P. 49.

4. Clearfield A. // Prog. Inorg. Chem. - 1998. - 47. - P. 371. Karlin K.D. (ed.). - New York: Wiley.

5. Maeda K. // Microporous Mesoporous Mater. - 2004. - 73. - P. 47.

6. Bellitto C. // Magn.: Mol. Mater. II. Miller J.S., Drillon M. (eds.). - New York: VCH, 2001.

7. Zhang Y.Y., Qi Y., Zhang Y., Liu Z.Y., Zhao Y.F., Liu Z.M. // Mater. Res. Bull. - 2007. - 42. - P. 1531.

8. Steel P.J. // Coord. Chem. Rev. - 1990. - 106. - P. 227.

9. Jia H.P., Li W., Ju Z.F., Zhang J. // J. Mol. Struct. - 2007. - 49. - P. 833.

10. Tuna F., Pascu G.I., Sutter J.P., Andruh M., Golhen S., Guillevic J., Pritzkow H. // Inorg. Chim. Acta. - 2003. - 131. - P. 342.

11. Schott O., Ferrando-Soria J., Bentama A., Stiriba S.E., Pasán J., Ruiz-Pérez C., Andruh M., Lloret F., Julve M. // Inorg. Chim. Acta. - 2011. - 376. - P. 358.

12. Holmes F., Jones K.M., Torrible E.G. // J. Chem. Soc. - 1961. - P. 4790.

13. Earnshaw A. // Introduction to Magnetochemistry. - London: Academic Press, 1968.

14. Sheldrik G.M. // Acta Crystallogr. - 1990. - A46. - P. 467.

15. Sheldrick G.M. Program for the Refinement of Crystal Structures, University of Göttingen, Germany, 1997.

16. Brandenburg K. Visual Crystal Structure Information System. Version 3.0, University of Bonn, Germany, 2003.

17. Castillo O., Luque A., Román P. // J. Mol. Struct. - 2001. - 570. - P. 181.

18. McCann M., Casey M.T., Derveux M., Curan M., McKee V. // Polyhedron. - 1997. - 16. - P. 2741. 
19. Addison A.W., Rao T.N., Reedijk J., van Rijn J., Verschoor G.C. // J. Chem. Soc., Dalton Trans. - 1984. - P. 1349.

20. Үи J.-H., Hou Q., Bi M.-H., Lü Z.-L., Zhang X., Qu X.-J., Lu J., Xu J.-Q. // J. Mol. Struct. - 2006. - 800. - P. 69.

21. Decurtins S., Schmalle H.W., Schneuwly P., Oswald H.R. // Inorg. Chem. - 1993. - 32. - P. 1888.

22. Abdelhak J., Cherni S.N., Zid M.F., Driss A. // Acta Crystallogr. - 2006. - E62. - P. m2394.

23. Karaa N., Hamdi B., Ben Salah A., Zouari R. // J. Mol. Struct. - 2013. - 1049. - P. 48.

24. Marinescu G., Visinescu D., Cucos A., Andruh M., Journaux Y., Kravtsov V., Simonov Y.A., Lipkowski J. // Eur. J. Inorg. Chem. - 2004. - P. 2914.

25. Wrobleski J.T., Brown D.B. // Inorg. Chem. - 1979. - 18. - P. 2738.

26. Zheng L.M., Fang X., Lii K.H., Song H.H., Xin X.Q., Fun H.K., Chinnakali K., Abdul Razak I. // J. Chem. Soc., Dalton Trans. - 1999. - P. 2311.

27. Lloret F., Julve M., Mollar M., Castro I., Latorre J., Faus J., Solans X., Morgenstern-Badarau I. // J. Chem. Soc., Dalton Trans. - 1989. - P. 729.

28. Czakis-Sulikowska D., Malinowska A., Radwañska-Doczekalska J. // Polish J. Chem. - 2000. - 74. - P. 607.

29. Pozdnyakov I.P., Kel O.V., Plyusnin V.F., Grivin V.P., Bazhin N.M. // J. Phys. Chem. A. - 2008. - 112. - P. 8316.

30. Snodin M.D., Oud-Moussa L., Wallmann U., Lecomte S., Bachler V., Bill E., Hummel H., Weyermüller T., Hildebrandt P., Wiegardt K. // Chem. Eur. J. - 1999. - 5. - P. 2554.

31. Palamarciuc O.V., Bourosh P.N., Revenco M.D., Lipkowski J., Simonov Y.A., Clérac R. // Inorg. Chim. Acta. - 2010. - 363. - P. 2561. 